\title{
Clinical significance of miR-21 expression in breast cancer: SYBR-Green I-based real-time RT-PCR study of invasive ductal carcinoma
}

\author{
GUAN-LI HUANG ${ }^{1}$, XIAO-HUA ZHANG ${ }^{1}$, GUI-LONG GUO ${ }^{1}$, KA-TE HUANG $^{2}$, \\ KAI-YAN YANG ${ }^{2}$, XIAN SHEN ${ }^{3}$, JIE YOU ${ }^{1}$ and XIAO-QU HU ${ }^{1}$ \\ Departments of ${ }^{1}$ Oncology, ${ }^{2}$ Pathology, and ${ }^{3}$ General Surgery, The First Affiliated Hospital of \\ Wenzhou Medical College, No.2, Fu Xue Road, 325000, Wenzhou, Zhejiang, P.R. China
}

Received September 10, 2008; Accepted November 19, 2008

DOI: 10.3892/or_00000270

\begin{abstract}
Growing evidence suggests microRNAs (miRNAs) have an important role in tumorigenesis. MicroRNA-21 (miR-21) is up-regulated in many malignant tumors, including breast cancer. Its association with clinicopathologic features and expression of PTEN (phosphatase and tensin homolog deleted on chromosome 10), one of its target genes, in breast cancer has not been reported systematically. To further determine the potential involvement of miR-21 in breast cancer, we have evaluated the expression level of miR-21 by stem-loop real-time RT-PCR based on SYBR-Green I in human invasive ductal carcinoma of the breast, and we have correlated the results with clinicopathologic features and PTEN protein expression. Matched non-tumor and tumor tissues of 40 human invasive ductal carcinoma of the breast were analyzed for miR-21 expression by stem-loop realtime RT-PCR based on SYBR-Green I. Immunohistochemistry (IHC) was used to estimate PTEN expression in tumor tissue. The expression levels of miR-21 were correlated with PTEN and commonly used clinicopathologic features of breast cancer. The stem-loop real-time RT-PCR based on SYBR-Green I was sensitive and specific enough to detect miR-21. Expression levels of miR-21 were significantly higher in tumor tissues than the levels in matched nontumor tissues $(\mathrm{P}=0.000)$. Expression of miR-21 was negatively correlated with expression of PTEN $(\mathrm{P}=0.013)$. Up-regulated miR-21 expression was associated with lymph node positivity $(\mathrm{P}=0.01)$, higher proliferation index $(\mathrm{Ki67}>10 \%)(\mathrm{P}=0.03)$ and advanced breast cancer TNM clinical stage $(\mathrm{P}=0.021)$. These findings suggest that PTEN is possibly one of the
\end{abstract}

Correspondence to: Dr Xiao-Hua Zhang, Department of Oncology, The First Affiliated Hospital of Wenzhou Medical College, No.2, Fu Xue Road, 325000, Wenzhou, Zhejiang, P.R. China

E-mail: zxhoncology@yahoo.com.cn

Key words: breast neoplasms, microRNAs, microRNA-21, human, PTEN phosphohydrolase, oncogenes, genes, tumor suppressor, SYBR-Green I, reverse transcriptase-polymerase chain reaction targets of miR-21 in breast cancer and high expression of miR-21 indicates a more aggressive phenotype.

\section{Introduction}

The initiation, progression and metastasis of a malignant tumor are usually caused by multiple genetic alterations. In the past few decades, researchers' attention has focused largely on the protein-coding genes that were classified into two groups: oncogenes and tumor suppressor genes. Recently miRNAs, which are endogenous, small, non-protein-coding RNAs that regulate gene expression post-transcriptionally by targeting mRNA transcripts for cleavage or translational repression (1), have provided new insights in cancer research. It is known that miRNAs can act as oncogenes by posttranscriptionally repressing the expression of target tumor suppressor genes, or as tumor suppressors by repressing the expression of target oncogenes. Bioinformatic data indicate that a single miRNA can control up to hundreds of target genes (2). miR-21 is up-regulated in many solid tumors, including lung, breast, prostate, and stomach carcinoma, pancreatic endocrine tumor, hepatocellular cancer (HCC) and glioblastoma (3-5). The fact that miR-21 is overexpressed in so many malignant tumors suggested that miR-21 functions as oncogene and its target genes should be tumor suppressors. It has been verified that PTEN, one of the most commonly affected tumor suppressor genes, like p53, was one of the target genes of miR-21 in HCC cell lines in vitro (5). PTEN expression is reduced in many solid tumors, including breast cancer. There are many reports that PTEN has an important role in tumorigenesis of breast cancer (6-9). It has been shown that reduced PTEN expression is associated with lymph node metastasis, estrogen receptor status, tumor grade, tumor-nodemetastasis (TNM) stage, and microvessel density (MVD), and it may be a valuable prognostic marker in breast cancer $(10,11)$. So, it is reasonable to propose that miR-21 regulating PTEN expression is a ubiquitous mechanism in solid tumors, including breast cancer.

Growing evidence shows that miR-21 is involved in antiapoptosis, tumor growth and chemosensitivity of tumor cells $(4,12-14)$. However, these pieces of evidence were mainly 
from experiments on cell lines in vitro or xenograft animal models. Therefore, the clinical significance of miR-21 in breast cancer was poorly understood. The correlation of miR-21 expression and PTEN or clinicopathologic features in human breast cancer has not been reported systematically. This correlation may help us to understand the function of miR-21 in breast cancer in vivo and its clinical significance. So, in the present study, we developed a novel highly sensitive and specific stem-loop real-time RT-PCR method based on SYBR-Green I to detect the expression of miR-21, which we correlated with PTEN and clinicopathologic features in human invasive ductal carcinoma of the breast. The use of similar method was reported only very recently for the detection of miRNA in plants (15). This method is far less costly than the method based on the TaqMan probe assay, and it can be used in the analysis of large numbers of samples in conventional laboratories.

\section{Materials and methods}

Tissue specimens and preparation of total RNA. Pairs of human primary invasive ductal carcinoma of breast cancer and adjacent non-tumorous tissues were obtained from 40 patients recruited from the Department of Oncology, The First Affiliated Hospital of Wenzhou Medical College in China between May 2007 and December 2007. Patients who had received neoadjuvant chemotherapy or radiation therapy before surgery were excluded from this study. All patients were treated by modified radical mastectomy. The resected tissues were divided into two parts, one part was stored in liquid nitrogen immediately after surgery, and the other was fixed in $10 \%$ buffered formaldehyde for pathologic diagnosis and immunohistochemical staining. Histopathologic diagnosis of invasive ductal carcinoma was carried out by the Department of Pathology, The First Affiliated Hospital of Wenzhou Medical College according to the criteria of the World Health Organization. The TNM classification was in accordance with the American Joint Committee on Cancer (AJCC) TNM Staging. The commonly used clinicopathologic features of breast cancer are given in Table I. Total RNA was isolated from the tissues using TRIzol reagent (Invitrogen Life Technologies) according to the manufacturer's instructions. RNA purity and concentration were controlled by UV spectrophotometry (A260:A280>1.8), RNA integrity was checked by denaturing agarose gel electrophoresis stained with ethidium bromide (EtBr).

Stem-loop real-time RT-PCR using SYBR-Green I. Stem-loop real-time RT-PCR was used in the analysis of miRNA expression. The primers for the analysis of miR-21 expression were designed according to Tang et al (16). The stem-loop RT primer was 5'-CTCAACTGGTGTCGTGGAGTCGG CAATTCAGTTGAGTCAACATC-3'. The forward primer was 5'-ACACTCCAGCTGGGTAGCTTATCAGACTGA-3'. The reverse primer was 5'-GTGTCGTGGAGTCGGCAA TTC-3'. Mixtures of $1 \mu \mathrm{g}$ of total RNAs together with $50 \mathrm{nM}$ reverse primer, $2 \mathrm{U}$ of RNAase inhibitor (Takara Bio), $5 \mathrm{U}$ of M-MLV reverse transcriptase (Takara Bio) and $0.5 \mu \mathrm{M}$ dNTP were used for each $\mathrm{RT}$ reaction. The reaction parameters were incubation at $16^{\circ} \mathrm{C}$ for $30 \mathrm{~min}, 42^{\circ} \mathrm{C}$ for $30 \mathrm{~min}, 70^{\circ} \mathrm{C}$ for
Table I. Correlation of the expression of miR-21 with clinicopathologic features and PTEN expression.

\begin{tabular}{lcc}
\hline $\begin{array}{l}\text { Clinicopathologic } \\
\text { features }\end{array}$ & $\mathrm{n}(\%)$ & $\begin{array}{c}\text { Relative expression } \\
\text { of miR-21 }\end{array}$
\end{tabular}

\begin{tabular}{lrl}
\hline $\begin{array}{l}\text { Menstrual status } \\
\text { Premenopausal }\end{array}$ & $16(40.0)$ & $5.075(2.868-7.025)$ \\
Postmenopausal & $24(60.0)$ & $6.185(4.443-7.738)$ \\
& & \\
Tumor size $(\mathrm{cm})^{c}$ & & \\
$\leq 2 \mathrm{~cm}$ & $17(42.5)$ & $5.110(2.900-7.535)$ \\
$>2 \mathrm{~cm}$ & $23(57.5)$ & $6.150(3.950-7.280)$ \\
TNM stage & & \\
I & $10(25.0)$ & $3.870(2.238-5.143)$ \\
II & $22(55.0)$ & $6.215(4.265-8.100)$ \\
III & $8(20.0)$ & $6.920(5.548-9.105)$
\end{tabular}

$\begin{array}{lll}\text { ER status } & & \\ \text { Positive } & 27(67.5) & 5.490(4.370-7.130) \\ \text { Negative } & 13(32.5) & 6.090(2.900-8.645)\end{array}$
PR status
Positive
$17(42.5) \quad 5.490(3.565-6.920)$
Negative
$23(57.5) \quad 6.090(3.490-7.950)$

Her-2

Positive

9 (22.5) $6.090(5.140-9.425)$

Negative

0.258

Lymph node

31 (77.5) $5.380(3.180-7.130)$

metastasis

Positive

$19(47.5) \quad 6.710(5.380-9.340)$

Negative

$21(52.5) \quad 4.660(2.900-6.215)$

Proliferation

index (Ki67)

$\begin{array}{lll}\leq 10 \% & 18(45.0) & 4.630(2.630-6.258) \\ >10 \% & 22(55.0) & 6.420(4.95-8.748)\end{array}$

Expression

0.013 of PTEN

$\begin{array}{lll}\text { High expression } & 22(55.0) & 4.850(3.020-6.355) \\ \text { Reduced } & 18(45.0) & 6.800(5.708-9.010) \\ \text { expression } & & \end{array}$

${ }^{a}$ Median of relative expression, with 25 th- 75 th percentile in parentheses. ${ }^{\mathrm{b}} \mathrm{P}<0.05$ was considered significant (Mann-Whitney U test between 2 groups and Kruskall-Wallis test for 3 groups). ${ }^{\mathrm{c}}$ Maximal tumor diameter.

$15 \mathrm{~min}$ and then kept at $4^{\circ} \mathrm{C}$. At the same time, to generate the cDNA template for the endogenous control PCR reactions, first strand cDNA was synthesized using $1 \mu \mathrm{g}$ of RNA from the same samples for stem-loop reverse transcription, and oligo(dT) as the primer. The reaction parameters were incubation at $42^{\circ} \mathrm{C}$ for $30 \mathrm{~min}, 70^{\circ} \mathrm{C}$ for $15 \mathrm{~min}$ and then kept at $4^{\circ} \mathrm{C}$. 

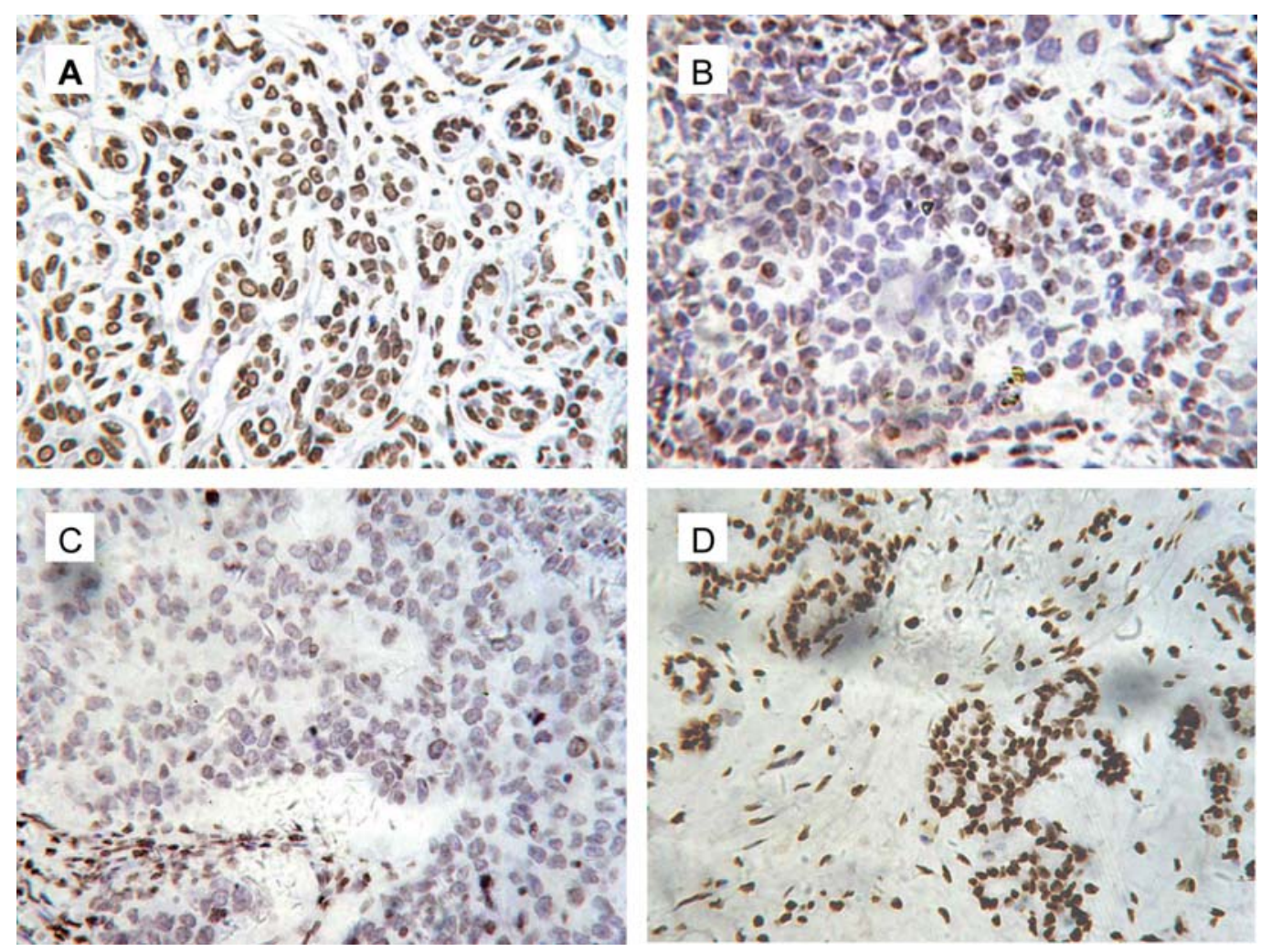

Figure 1. Representative results of immunohistochemical staining of PTEN in tumor tissues and non-tumor tissue of invasive ductal carcinoma of the breast cancer. (A) High PTEN expression ( $>50 \%$ tumor cells were stained, defined as ++ ) in the nuclei of the breast cancer cells (original magnification $x 400$ ). (B) Reduced PTEN expression ( $<50 \%$ tumor cells were stained, difined as + ) in breast cancer (original magnification $\mathrm{x} 400$ ). (C) PTEN expression in breast cancer cells is almost absolutely lost ( $<10 \%$ tumor cells were stained, defined as -$)$, only some non-tumorous stromal cells (lower left corner) were stained (original magnification $\mathrm{x} 400$ ). (D) PTEN is high expressed in the nuclei of benign duct epithelial cells (original magnification $\mathrm{x} 400$ ).

Real-time PCR was done with an Applied Biosystems 7500 detection system in a $15 \mu 1$ reaction volume. All reactions were done in triplicate. For quantitation of the miR-21, the $15 \mu \mathrm{l}$ PCR included $1 \mu 1$ of the RT product of miR-21, 1X SYBR-Green I Mastermix (Toyobo Co., Ltd.), $0.5 \mu \mathrm{M}$ specific forward primer of miR-21 and $0.5 \mu \mathrm{M}$ reverse primer. For the endogenous control, GAPDH, $1 \mu 1$ of cDNAs synthesized by using oligo(dT) were used as template. The GAPDH primers were: forward 5'-CAGG GCTGCTTTTAACTCTGGTAA-3' and reverse 5'-GGGTGG AATCATATTGGAACATGT-3'. The reaction parameters were incubation at $95^{\circ} \mathrm{C}$ for $10 \mathrm{~min}$, then 40 cycles of $95^{\circ} \mathrm{C}$ for $15 \mathrm{sec}, 60^{\circ} \mathrm{C}$ for $1 \mathrm{~min}$. The threshold cycle $(\mathrm{Ct})$ is defined as the cycle number at which the fluorescence passed a pre-determined threshold. For expression analysis, the experiment was designed to use the matched nontumor tissue as the control, so the relative quantification of miR-21 in tumor tissue was calculated using the equation: amount of target $=2^{-\Delta \Delta \mathrm{Ct}}(17), \Delta \Delta \mathrm{Ct}=\left(\mathrm{Ct}_{\mathrm{miR}-21}-\mathrm{Ct}_{\mathrm{GAPDH}}\right)_{\mathrm{tumor}^{-}}$ $\left(\mathrm{Ct}_{\text {miR-21 }}-\mathrm{Ct}_{\mathrm{GAPDH}}\right)_{\text {matched non-tumor }}$. For the matched non-tumor tissue control sample, $\Delta \Delta \mathrm{Ct}$ is zero and $2^{-\Delta \Delta \mathrm{Ct}}$ is 1 . Melting curves were generated and $8 \%$ PAGE electrophoresis was performed for each real-time PCR to verify the amplification of only the desired product.

Immunohistochemistry. We examined the expression of PTEN in invasive ductal carcinoma of the breast by immunohistochemical staining of the 40 tumor samples and 10 random matched non-tumor samples. Sections $(4 \mu \mathrm{m})$ were cut from formalin-fixed, paraffin-embedded tissues that were mounted on poly(L-lysine)-coated slides. After deparaffinization in xylene and hydration in graded ethanol solutions, the sections were treated with $10 \mathrm{mM}$ citrate buffer ( $\mathrm{pH} \mathrm{6.0)} \mathrm{in} \mathrm{a} \mathrm{pressure-cooker} \mathrm{for} 4 \mathrm{~min}$ at $120^{\circ} \mathrm{C}$. For quenching of the endogenous peroxidase, sections were treated with $3 \%$ hydrogen peroxide in methanol for $15 \mathrm{~min}$. After washing with phosphate-buffered saline (PBS), the sections were incubated with primary PTEN mouse monoclonal antibody (28H6, Novocastra Laboratories Ltd.) at 1:100 dilution in a moist chamber overnight at $4^{\circ} \mathrm{C}$. After washing with PBS, the sections were incubated with Polymer Helper and polyperoxidase anti-mouse/rabbit IgG (Polymer Detection System, PV-9000, GBI) according to the manufacturer's protocol. Color was developed with 3,3'-diaminobenzidine tetrahydrochloride (DAB). As a negative control, primary antibody was replaced by PBS. Finally, the slides were lightly counterstained with hematoxylin. The slides were examined with a standard light microscope independently by two pathologists who had no knowledge of any patient's clinicopathological data. Brown staining on the nucleus was considered as positive immunoreactivity (Fig. 1), and was evaluated as percentage staining over the whole preparation. Expression of PTEN was graded as follows: - , <10\% of cells stained;,$+ 10-50 \%$ of cells stained;,$++>50 \%$ of cells stained. Reduced expression of PTEN was defined as either + or -, and high expression was defined as ++. 
A

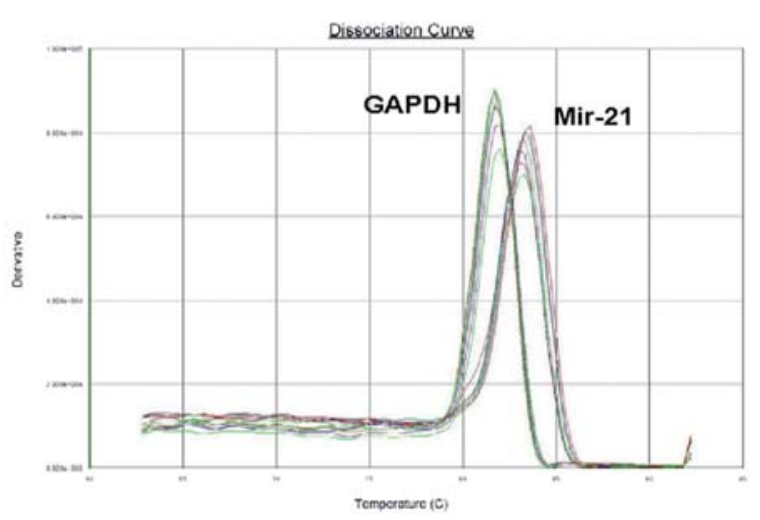

C

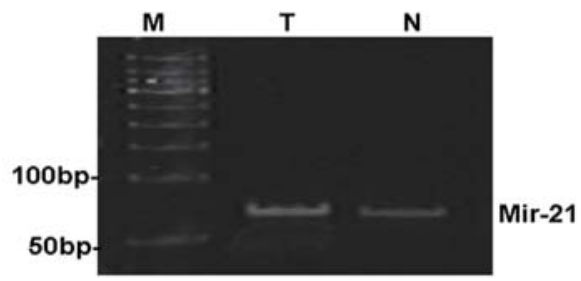

B
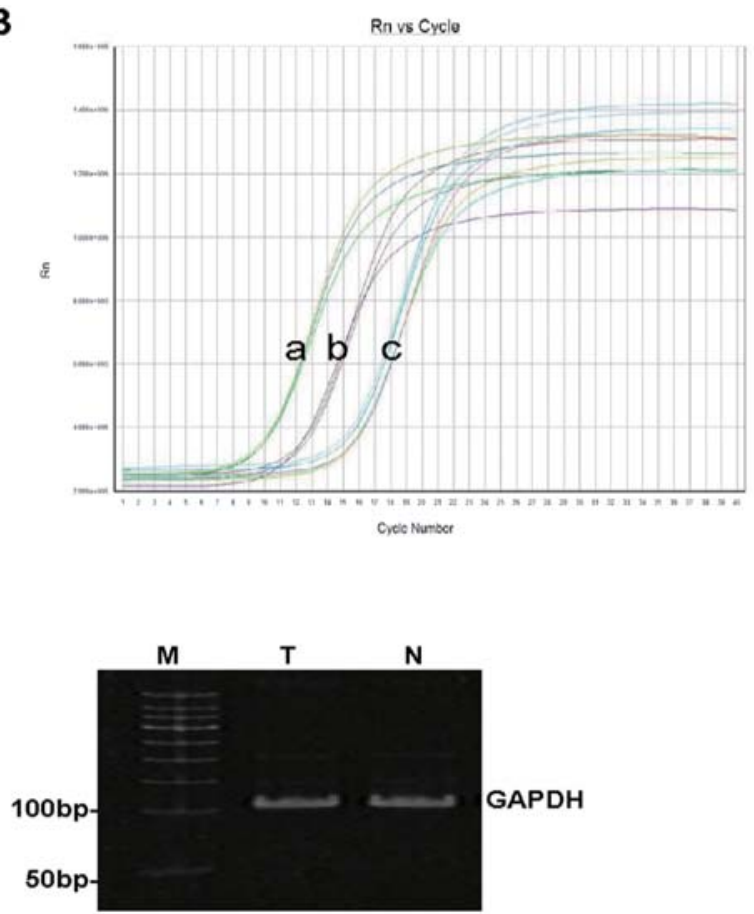

Figure 2. Characteristics of the stem-loop real-time RT-PCR based on SYBR-Green I for miR-21 expression in human invasive ductal carcinoma of the breast cancer. (A) The melting-curves of miR-21 and GAPDH are presented as a single, sharply defined melting curve with a narrow peak, indicating that pure, homogeneous PCR products were produced. (B) Representative amplification curves showed that the Ct values of miR-21 in tumor tissue are lower than in non-tumor tissue, indicating the miR-21 expression is higher in tumor tissue than in non-tumor tissue. Reactions were done in triplicate. (a) miR-21 of tumor; (b) miR-21 of matched non-tumor; (c) GAPDH of tumor and matched non-tumor. (C) Amplicons were analyzed by $8 \%$ PAGE electrophoresis. Single bands of miR-21 at 67 bp position and GAPDH at $101 \mathrm{bp}$ position indicated that the PCR products were as desired (M, DNA marker; T, tumor; N, non-tumor).

Statistical analysis. As the data for miR-21 relative expression levels did not fit a Gaussian distribution, the miR-21 levels were characterized by their median and ranges from the 25 th to the 75th percentile, rather than their mean and coefficient of variation. The expression of miR-21 was calculated for different groups using non-parametric tests: the Wilcoxon test for comparing 2 paired groups (tumor and paired nontumor), the Mann-Whitney U test for 2 independent groups, and the Kruskall-Wallis test for 3 independent groups. The criterion for statistical significance was set at $\mathrm{P}<0.05$, and all calculations were done with SPSS 13.0 software.

\section{Results}

Expression of miR-21 in tumor tissue and matched nontumor tissue detected by SYBR-Green I-based stem-loop realtime RT-PCR. The melting-curves of miR-21 and GAPDH were sharply defined curves with a narrow peak, indicating that pure, homogeneous PCR products were produced (Fig. 2A). A single band of miR-21 or GAPDH at the appropriate position (67 bp for miR-21 and $101 \mathrm{bp}$ for GAPDH) on the electrophoresis gel indicated that the PCR product was what we desired (Fig. 2C). The combination of melting curves and gel electrophoresis confirmed the PCR specificity. As shown in the representative amplification curves (Fig. 2B), the $\mathrm{Ct}$ value of miR-21 in tumor tissue was lower than that of miR-21 in non-tumor tissue, which means that the expression level of miR-21 in tumor samples was higher than that in the controls. The median of relative expression of miR-21(2- $\left.2^{-\Delta \Delta t}\right)$ was 5.770 (25th-75th percentile, 3.605-7.255) in tumor

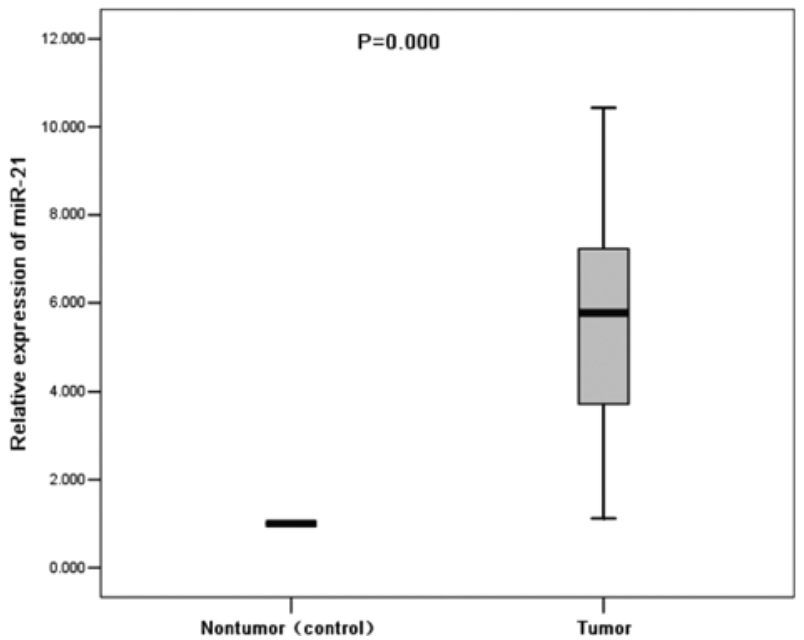

Figure 3. Differences in expression levels of miR-21 between invasive ductal carcinoma of breast cancer and matched non-tumor tissue which was used as control (box-plot diagrams with median, 1st quartile, 3rd quartile and non-outlier range).

samples, with that in non-tumor control samples set at 1.000 (Fig. 3). The difference of expression of miR-21 between the tumor and the control samples was statistically significant $(\mathrm{P}=0.000$, Wilcoxon test $)$.

Association between the expression of miR-21, clinicopathologic features, and expression of PTEN. The up-regulated expression of miR-21 was associated with advanced clinical 


\section{A}

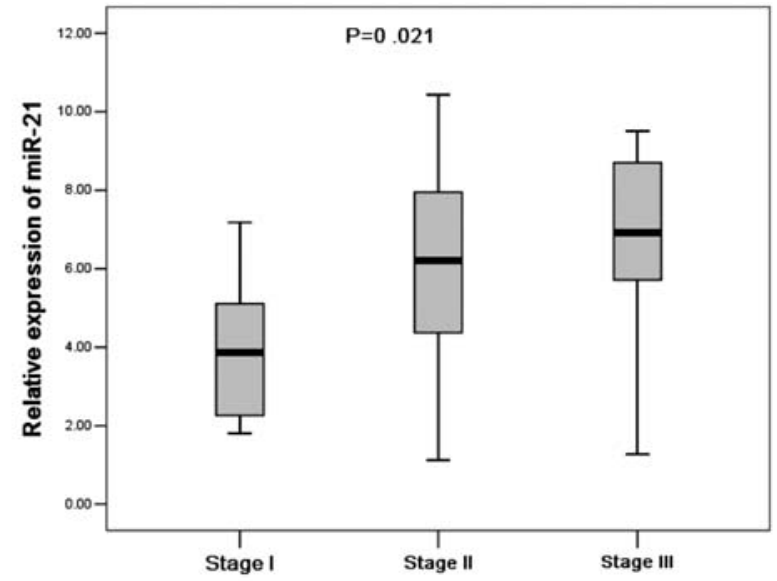

\section{C}

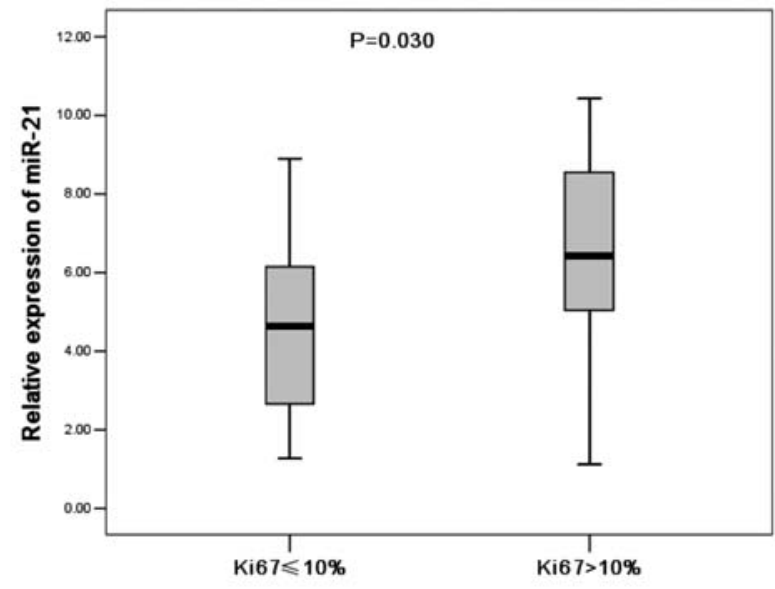

B

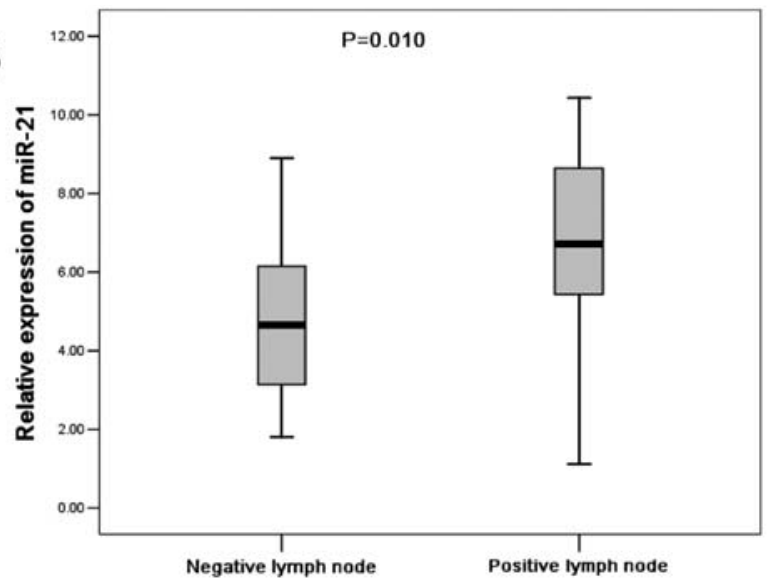

D

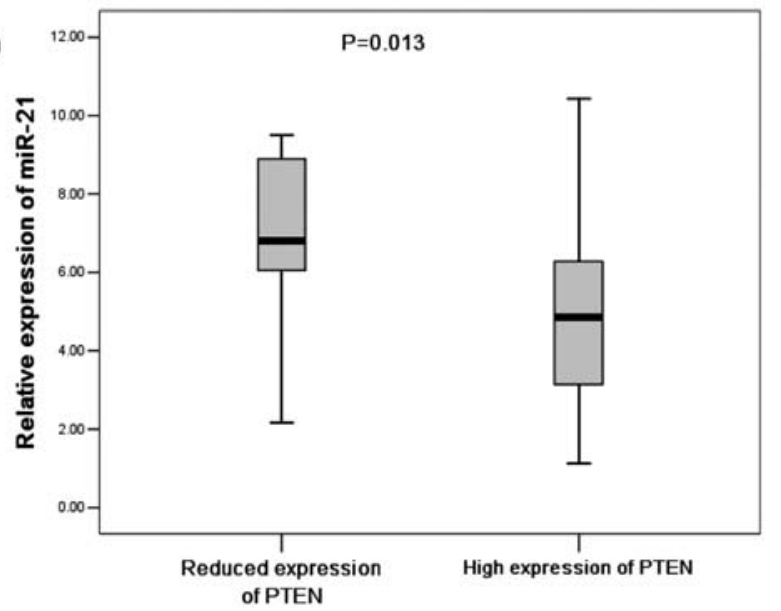

Figure 4. Association of miR-21 expression with (A) clinical TNM stage, (B) lymph node metastasis, (C) proliferation index and (D) PTEN expression (box-plot diagrams with median, 1st quartile, 3rd quartile and non-outlier range).

TNM stage ( $\mathrm{P}=0.021$, Kruskall-Wallis test, Fig. 4A), lymph node positivity $(\mathrm{P}=0.01$, Mann-Whitney $\mathrm{U}$ test, Fig. 4B) and a high proliferation index (Ki-67>10\%) ( $\mathrm{P}=0.03$, MannWhitney U test, Fig. 4C). Furthermore, expression of miR-21 was significantly higher in tumors with reduced expression of PTEN ( $\mathrm{P}=0.013$, Mann-Whitney U test, Fig. 4D). While no significant association was found between expression of miR-21 and menstrual status $(\mathrm{P}=0.258$, Mann-Whitney $\mathrm{U}$ test $)$, size of primary tumor $(\mathrm{P}=0.575$, Mann-Whitney $\mathrm{U}$ test), ER status ( $\mathrm{P}=0.762$, Mann-Whitney $\mathrm{U}$ test), $\mathrm{PR}$ status ( $\mathrm{P}=0.556$, Mann-Whitney $\mathrm{U}$ test) and Her-2 status $(\mathrm{P}=0.556$, Mann-Whitney U test). Data are given in Table I as medians of the relative expression values, with ranges defined as 25 th to 75 th percentiles, and P-values.

\section{Discussion}

As described above, miR-21 seems to play an important oncogenic role in malignant tumors. As to breast cancer, several studies have proved miR-21 was up-regulated in breast cancer both in vivo and in vitro by different kinds of method including Northern blotting (18), microarray $(18,19)$, beadbased flow cytometric miRNA expression profiling method (20), in situ hybridization (ISH) (21), bioluminescencebased hybridization assay (22) and real-time RT-PCR (12). A few of these studies correlated the miR-21 expression with the clinicopathologic features. However, only Iorio et al (18) reported that overexpression of miR-21 which was detected by microarray was correlated with higher tumor stage. Among these methods, real-time RT-PCR is the most sensitive, specific and accurate. So, in order to affirm whether miR-21 expression was correlated with clinicopathologic features, in this study, we developed a novel stem-loop real-time RTPCR methods to detect miR-21 expression, which used costeffective SYBR-Green I instead of commonly used high price TaqMan probe $(16,23,24)$ for fluorescence assays in real-time PCR. The amplification, melting curves and electrophoresis gel, as shown in Fig. 2, indicate the method is specific and sensitive enough for detection of miR-21. Furthermore, to reduce error caused by gene expression difference between different individuals, we used matched non-tumor tissue as control and used $2^{-\Delta \Delta C t}$ to represent the level of miR-21 expression in tumor relative to matched non-tumor. As expected, our result confirmed that miR-21 expression was upregulated in breast cancer compared with the matched nontumor tissue, and that up-regulated expression of miR-21 was not only correlated with higher tumor stage as Iorio et al (18) have reported, but also associated with lymph node positivity, and higher proliferation index (Ki67>10\%) which are well-known poor prognostic factors for breast cancer (25-28) and have been routinely applied clinically. These results indicate that breast cancer with overexpression of 
miR-21 may be more aggressive, thus, miR-21 has an important role in progression, invasion and dissemination of human breast cancer in vivo.

Like most other malignant tumors, development, progression, invasion and metastasis of breast cancer are caused by multiple genetic alterations, which mechanism was not elucidated completely until now. The discovery of miRNAs provides new insights. It was predicted that one miRNA could be able to down-regulate multiple target genes simultaneously, so miRNAs may be able to act as efficient regulators of tumor-related genes in tumors. Changes in the expression of miRNAs have been observed in breast cancer $(3,18)$, and whether these changes are the cause of tumorigenesis is being studied. Identification of the target genes of these altered miRNAs is critical to understanding their mechanism in tumor pathogenesis. At least 3 genes have been identified as targets of miR-21 (5,29-31). PTEN is among them, and that its expression can be repressed by miR-21 was affirmed in HCC cell lines (5). However, the relationship between miR-21 and PTEN in breast cancer is not known. There is evidence that reduced expression of PTEN is associated with tumor progression and poor outcome in breast cancer $(11,32,33)$, but the mechanism of PTEN down-regulation in breast cancer is not clear. Some studies found that the incidence of loss of heterozygosity $(\mathrm{LOH})$ in PTEN was approximately $40 \%$ in breast cancer $(34,35)$, but a further study showed that this level of $\mathrm{LOH}$ is not sufficient to reduce the expression of PTEN (32). The mutation of PTEN in breast cancer is at a low frequency, only about $5 \%$ (36). However, in breast cancer the reduced expression of PTEN ranged from 33 to $48 \%$ in various immunohistochemical studies $(10,32,37)$. In accordance with these reports, our study showed a reduced PTEN expression of $45 \%$ (18/40). Thus, it can be that other mechanisms, such as post-transcriptional down-regulation could be involved in PTEN inactivation in breast cancer. Our study showed that miR-21 expression was significantly different between reduced PTEN expressing and high PTEN expressing subgroups. Combined with the evidence obtained with the HCC cell line, our study implied that it is very possible that PTEN is also the target of miR-21 in breast cancer; therefore, the reduced PTEN expression may be caused, at least partly, by miR-21, which may be involved in tumorigenesis of breast cancer at least partly through the PTEN pathway.

Until very recently, besides PTEN, there were 2 other tumor suppressor genes known to be targets of miR-21; they are Tropomyosin 1 (TPM 1), with miR-21 in breast cancer cells (31), and programmed cell death 4 (PDCD 4), which was shown to be associated with miR-21 in colorectal cancer cells and in breast cancer cells $(29,30)$. Although these genes were not studied in-depth in breast cancer, there was preliminary evidence to suggest that they act as suppressor genes in breast cancer and other tumors (38-42). The current results together with previously reported evidence suggest that miR-21 may enhance malignant phenotype of breast cancer by repressing expression of multiple tumor suppressor genes simultaneously, and there may be more target genes which still have not been found. Theoretically, repressing the expression of miR-21 may result in the restoration of expression of large numbers of tumor suppressor genes, so
miR-21 provides an attractive molecular target for decreasing invasiveness and the metastatic properties of breast cancer. Whether miR-21 could function as a prognostic factor or a molecular target in the treatment of human breast cancer awaits clarification from the follow-up of these patients and further research.

\section{Acknowledgements}

This study was supported by Zhejiang Provincial Natural Science Foundation of China (No.Y207301). We would like to thank Xiang-Yan Xue for critical review of the manuscript.

\section{References}

1. Bartel DP: MicroRNAs: genomics, biogenesis, mechanism and function. Cell 116: 281-297, 2004 .

2. Wu W, Sun M, Zou GM and Chen J: MicroRNA and cancer: current status and prospective. Int J Cancer 120: 953-960, 2007.

3. Volinia S, Calin GA, Liu CG, Ambs S, Cimmino A, Petrocca F, Visone R, Iorio M, Roldo C, Ferracin M, Prueitt RL, Yanaihara N, Lanza G, Scarpa A, Vecchione A, Negrini M, Harris CC and Croce CM: A microRNA expression signature of human solid tumors defines cancer gene targets. Proc Natl Acad Sci USA 103: 2257-2261, 2006.

4. Chan JA, Krichevsky AM and Kosik KS: MicroRNA-21 is an antiapoptotic factor in human glioblastoma cells. Cancer Res 65: 6029-6033, 2005.

5. Meng F, Henson R, Wehbe-Janek H, Ghoshal K, Jacob ST and Patel T: MicroRNA-21 regulates expression of the PTEN tumor suppressor gene in human hepatocellular cancer. Gastroenterology 133: 647-658, 2007.

6. Li J, Simpson L, Takahashi M, Miliaresis C, Myers MP, Tonks N and Parsons R: The PTEN/MMAC1 tumor suppressor induces cell death that is rescued by the AKT/protein kinase B oncogene. Cancer Res 58: 5667-5672, 1998.

7. Tamura M, Gu J, Matsumoto K, Aota S, Parsons R and Yamada KM: Inhibition of cell migration, spreading, and focal adhesions by tumor suppressor PTEN. Science 280: 1614-1617, 1998.

8. Weng LP, Smith WM, Dahia PL, Ziebold U, Gil E, Lees JA and Eng C: PTEN suppresses breast cancer cell growth by phosphatase activity-dependent G1 arrest followed by cell death. Cancer Res 59: 5808-5814, 1999

9. Tamura M, Gu J, Takino T and Yamada KM: Tumor suppressor PTEN inhibition of cell invasion, migration, and growth: differential involvement of focal adhesion kinase and p130Cas. Cancer Res 59: 442-449, 1999.

10. Depowski PL, Rosenthal SI and Ross JS: Loss of expression of the PTEN gene protein product is associated with poor outcome in breast cancer. Mod Pathol 14: 672-676, 2001

11. Lee JS, Kim HS, Kim YB, Lee MC, Park CS and Min KW: Reduced PTEN expression is associated with poor outcome and angiogenesis in invasive ductal carcinoma of the breast. Appl Immunohistochem Mol Morphol 12: 205-210, 2004.

12. Si ML, Zhu S, Wu H, Lu Z, Wu F and Mo YY: miR-21mediated tumor growth. Oncogene 26: 2799-2803, 2007.

13. Meng F, Henson R, Lang M, Wehbe H, Maheshwari S, Mendell JT, Jiang J, Schmittgen TD and Patel T: Involvement of human micro-RNA in growth and response to chemotherapy in human cholangiocarcinoma cell lines. Gastroenterology 130: 2113-2129, 2006

14. Blower PE, Chung JH, Verducci JS, Lin S, Park JK, Dai Z, Liu CG, Schmittgen TD, Reinhold WC, Croce CM, Weinstein JN and Sadee W: MicroRNAs modulate the chemosensitivity of tumor cells. Mol Cancer Ther 7: 1-9, 2008.

15. Varkonyi-Gasic E, Wu R, Wood M, Walton EF and Hellens RP: Protocol: a highly sensitive RT-PCR method for detection and quantification of microRNAs. Plant Methods 3: 12, 2007.

16. Tang F, Hajkova P, Barton SC, Lao K and Surani MA: MicroRNA expression profiling of single whole embryonic stem cells. Nucleic Acids Res 34: e9, 2006

17. Livak KJ and Schmittgen TD: Analysis of relative gene expression data using real-time quantitative PCR and the 2(-Delta Delta C(T)) Method. Methods 25: 402-408, 2001. 
18. Iorio MV, Ferracin M, Liu CG, Veronese A, Spizzo R, Sabbioni S, Magri E, Pedriali M, Fabbri M, Campiglio M, Menard S, Palazzo JP, Rosenberg A, Musiani P, Volinia S, Nenci I, Calin GA, Querzoli P, Negrini M and Croce CM: MicroRNA gene expression deregulation in human breast cancer. Cancer Res 65: 7065-7070, 2005.

19. Mattie MD, Benz CC, Bowers J, Sensinger K, Wong L, Scott GK, Fedele V, Ginzinger D, Getts R and Haqq C: Optimized highthroughput microRNA expression profiling provides novel biomarker assessment of clinical prostate and breast cancer biopsies. Mol Cancer 5: 24, 2006.

20. Blenkiron C, Goldstein LD, Thorne NP, Spiteri I, Chin SF, Dunning MJ, Barbosa-Morais NL, Teschendorff AE, Green AR, Ellis IO, Tavare S, Caldas C and Miska EA: MicroRNA expression profiling of human breast cancer identifies new markers of tumor subtype. Genome Biol 8: R214, 2007.

21. Sempere LF, Christensen M, Silahtaroglu A, Bak M, Heath CV Schwartz G, Wells W, Kauppinen S and Cole CN: Altered MicroRNA expression confined to specific epithelial cell subpopulations in breast cancer. Cancer Res 67: 11612-11620 2007.

22. Cissell KA, Rahimi Y, Shrestha S, Hunt EA and Deo SK: Bioluminescence-based detection of microRNA, miR21 in breast cancer cells. Anal Chem 80: 2319-2325, 2008.

23. Chen C, Ridzon DA, Broomer AJ, Zhou Z, Lee DH, Nguyen JT, Barbisin M, Xu NL, Mahuvakar VR, Andersen MR, Lao KQ, Livak KJ and Guegler KJ: Real-time quantification of microRNAs by stem-loop RT-PCR. Nucleic Acids Res 33: e179, 2005.

24. Lao K, Xu NL, Sun YA, Livak KJ and Straus NA: Real-time PCR profiling of 330 human micro-RNAs. Biotechnol J 2: $33-35,2007$

25. Fisher B, Bauer M, Wickerham DL, et al: Relation of number of positive axillary nodes to the prognosis of patients with primary breast cancer. An NSABP update. Cancer 52: 1551-1557, 1983

26. Carter CL, Allen C and Henson DE: Relation of tumor size, lymph node status, and survival in 24,740 breast cancer cases. Cancer 63: 181-187, 1989

27. Trihia H, Murray S, Price K, Gelber RD, Golouh R, Goldhirsch A, Coates AS, Collins J, Castiglione-Gertsch M and Gusterson BA: Ki-67 expression in breast carcinoma: its association with grading systems, clinical parameters, and other prognostic factors - a surrogate marker? Cancer 97: 1321-1331, 2003.

28. De Azambuja E, Cardoso F, de Castro G Jr, Colozza M, Mano MS, Durbecq V, Sotiriou C, Larsimont D, PiccartGebhart MJ and Paesmans M: Ki-67 as prognostic marker in early breast cancer: a meta-analysis of published studies involving 12,155 patients. Br J Cancer 96: 1504-1513, 2007.

29. Asangani IA, Rasheed SA, Nikolova DA, Leupold JH, Colburn NH, Post S and Allgayer H: MicroRNA-21 (miR-21) post-transcriptionally downregulates tumor suppressor Pdcd4 and stimulates invasion, intravasation and metastasis in colorectal cancer. Oncogene 27: 2128-2136, 2008
30. Frankel LB, Christoffersen NR, Jacobsen A, Lindow M, Krogh A and Lund AH: Programmed cell death 4 (PDCD4) is an important functional target of the MicroRNA miR-21 in breast cancer cells. J Biol Chem 283: 1026-1033, 2008.

31. Zhu S, Si ML, Wu H and Mo YY: MicroRNA-21 targets the tumor suppressor gene tropomyosin 1 (TPM1). J Biol Chem 282: 14328-14336, 2007.

32. Bose S, Crane A, Hibshoosh H, Mansukhani M, Sandweis L and Parsons R: Reduced expression of PTEN correlates with breast cancer progression. Hum Pathol 33: 405-409, 2002.

33. Piekarski JH and Biernat W: Clinical significance of CK5/6 and PTEN protein expression in patients with bilateral breast carcinoma. Histopathology 49: 248-255, 2006.

34. Feilotter HE, Coulon V, McVeigh JL, Boag AH, Dorion-Bonnet F Duboue B, Latham WC, Eng C, Mulligan LM and Longy M: Analysis of the $10 \mathrm{q} 23$ chromosomal region and the PTEN gene in human sporadic breast carcinoma. Br J Cancer 79: 718-723, 1999

35. Singh B, Ittmann MM and Krolewski JJ: Sporadic breast cancers exhibit loss of heterozygosity on chromosome segment 10q23 close to the Cowden disease locus. Genes Chromosomes Cancer 21: 166-171, 1998 .

36. Ali IU, Schriml LM and Dean M: Mutational spectra of PTEN/ MMAC1 gene: a tumor suppressor with lipid phosphatase activity. J Natl Cancer Inst 91: 1922-1932, 1999

37. Perren A, Weng LP, Boag AH, Ziebold U, Thakore K, Dahia PL, Komminoth P, Lees JA, Mulligan LM, Mutter GL and Eng C: Immunohistochemical evidence of loss of PTEN expression in primary ductal adenocarcinomas of the breast. Am J Pathol 155: 1253-1260, 1999.

38. Nieves-Alicea R, Colburn NH, Simeone AM and Tari AM: Programmed cell death 4 inhibits breast cancer cell invasion by increasing tissueinhibitor of metalloproteinases-2 expression. Breast Cancer Res Treat (In press).

39. Mahadev K, Raval G, Bharadwaj S, Willingham MC, Lange EM, Vonderhaar B, Salomon D and Prasad GL: Suppression of the transformed phenotype of breast cancer by tropomyosin-1. Exp Cell Res 279: 40-51, 2002.

40. Afonja O, Juste D, Das S, Matsuhashi S and Samuels HH: Induction of PDCD4 tumor suppressor gene expression by RAR agonists, antiestrogen and HER-2/neu antagonist in breast cancer cells. Evidence for a role in apoptosis. Oncogene 23: 8135-8145, 2004

41. Raval GN, Bharadwaj S, Levine EA, Willingham MC, Geary RL, Kute T and Prasad GL: Loss of expression of tropomyosin-1, a novel class II tumor suppressor that induces anoikis, in primary breast tumors. Oncogene 22: 6194-6203, 2003.

42. Wen YH, Shi X, Chiriboga L, Matsahashi S, Yee H and Afonja O: Alterations in the expression of PDCD4 in ductal carcinoma of the breast. Oncol Rep 18: 1387-1393, 2007. 